\title{
OBITUARIES
}

\section{Prof. H. U. Sverdrup}

Harado Ulrik Sverdrup, who died very suddenly on August 21, was born in November 1888. He was a relative of Otto Sverdrup, who had been Nansen's captain on the Fram and who was himself the discoverer of a great fjord region west of Ellesmere Land.

Sverdrup became assistant to Prof. Bjerknes in Oslo in 1911, but during 1913-17 studied in Leipzig. From 1917 until 1925 he was leader of research on the Maud Expedition led by Roald Amundsen and during this period obtained an intimate knowledge of the Arctic. He was appointed a Research Fellow at the Carnegie Institution of Magnetic Resoarch in 1922. From 1926 until 1931 he was professor of meteorology in the Geophysical Institute in Bergen. In 1931, when Sir Hubert Wilkins planned an expedition towards the North Pole in the submarine Nautilus, Sverdrup gave him full support. Unfortunately, apart from dives at the edge of the sea ice, Wilkins was never able to carry out his plans and the submarine was scuttled off Bergon in November of that same year. In 1934 Sverdrup took part in an expedition to North West Spitsbergen, with his close friend, Prof. H. W. Ahlmann, to study heat exchange between the atmosphere and the snow surface in these high latitudes. Sverdrup was appointed director of the Scripps Institution of Oceanography in California and was professor in the University of California during 1936-48. $\mathrm{He}$ was invited to become director of the Norwegian Polar Institute in 1948 and in 1949 became professor of geophysics in the University of Oslo.

H. U. Sverdrup's career was quite unusual, and there is no one else who has ever combined a special knowledge of mathematics and physics with familiarity in the field with problems both in the Antaretic and in the Aretic. $\mathrm{He}$ is known to a very large number as one of the three authors, the others being Martin W. Johnson and R. H. Fleming, of "The Oceans", published in 1942, which will long remain the most extensive text-book on oceanography. He is equally well known, however, to the smaller number who have been associated with him in polar science. Sverdrup was responsible for the home control of the Norwegian-BritishSwedish Expedition to Queen Maud Land in 1949-52, and himself visited Moudheim in January 1951. His polar knowledge was extremely varied. Anyone anxious to obtain information, for example, on sea ice would rely very largely on Sverdrup's opinion, and his views on this subject were invaluable at the time that the Royal Society's Expedition to Halley Bay was under consideration. This, however, was only one of the many fields of rare and unusual knowledge which he covered and which have made him unique among explorers.

J. M. WORDIE

\section{Prof. W. N. Benson, F.R.S.}

WiTH the death on August 20 of emeritus professor W. N. Benson, of the University of Otago, New Zealand has lost the doyen of her geologists. He passed away after a brief illness, although his general health had given concern for some time.

William Noël Benson was born near London on December 26, 1885, the son of an Australian shipping manager. He was educated at the Friends' High School in Hobart and later at the University of Hobart and the University of Sydney, where he came under the influence of the inspiring personality and teaching of Sir Edgeworth David. While still at Sydney, and before even graduating B.Se. in 1907, he published a paper on the contact aureole of a granitic body. This early irruption into the field of original inquiry initiated a career that was always devoted primarily to research. The topics he investigated were to involve work in virtually all the geological sciences, though he made especially significant contributions on the interplay of tectonics and magmatism. His work was followed with extraordinary energy, enthusiasm and persistence. All his former students will remember his well-loved figure forging ahead in front of panting field-parties, and in his office, when too tired for other work he would turn to drafting maps and block diagrams, an occupation which, he maintained, did not require great mental effort. He handled a very heavy teaching load, being professor of geology in the University of Otago without any assistant during 1916-26 and with only one assistant (F. J. Turner) for all but three of the remaining years before he retired from active teaching at the end of 1949 .

In 1908 Benson acted for a year as lecturer in mineralogy and petrology in the University of Adelaide. Three papers followed, two of them on petrological problems and one on the fault-block structure of the Mt. Lofty Ranges. Back in Sydney during 1909-11 as demonstrator in petrology, he began his classic study of the geology and petrology of the Great Serpentine Belt of New South Wales; which he continued first as 1851 Science Research Scholar at Cambridge under Harker, Bonney and Marr (1911-13), and later (1914-16) as Research Fellow and lecturer in Sydney. The resulting long series of papers culminated in two notable publica. tions that appeared after his appointment to Otago"The Origin of Serpentine" (1918) and "Tectonic Conditions accompanying the Intrusion of Basic and Ultrabasic Igneous Rocks" (Mem. U.S. Nat. Acad. Sici., 1926).

In Dunedin, he quickly turned his attention to problems of New Zealand geology as well as its relation to the south-west Pacific as a whole. $\mathrm{He}_{\mathrm{e}}$ carried out important researches on New Zealand's then little-known Ordovician rocks and on their graptolite faunas. His geomorphic observations in Fiordland and in the Dunedin district led to the important concept of both a Cretaceous peneplain in the South Island, and a late Cainozoic erosion surface truncating it and later sediments. $\mathrm{H}_{\Theta}$ also showed that the so-called block mountains of eastern Otago are essentially fault-folds of more or less Saxonian type. His last major discovery was that of the first Cambrian rocks to be found in New Zealand, a brief account of which was published shortly before his death. Benson's major work in New Zealand, however, was undoubtedly his long and detailed study of the late Cainozoic East Otago Petrographic Province. Numerous papers on this and on related topics have already appeared, but a comprehensive memoir is still to be published. Progressive crustal movements are shown to have occurred during the 